\title{
PERUBAHAN ORGANISASI LEMBAGA PENDIDIKAN ISLAM DALAM MENGHADAPI PERSAINGAN GLOBAL
}

\author{
Mundzar Fahman \\ Institut Agama Islam Sunan Giri Bojonegoro \\ mfahman2002@yahoo.com
}

\begin{abstract}
ABSTRAK
"Dalam sebuah wacana perubahan oganisasi pendidikan di era Global, selalu saja keberhasilan atau kegagalan suatu organisasi dalam mencapai tujuan yang ditetapkan, biasanya diatribusikan sebagai akibat dari kepemimpinan. Begitu pentingnya masalah perubahan organisasi pendidikan ini, menjadikan pemimpin selalu menjadi fokus atribusi terhadap keberhasilan dan kegagalan organisasi. Sukses dari suatu kepemimpinan didukung oleh kemampuan menangkap perubahan-perubahan yang terjadi di dalam suatu organisasi yang terjadi sangat cepat, sulit diprediksi, dan berefek sangat luas di era globalisasi dan persaingan pada saat ini. Perubahan-perubahan global memunculkan fenomena kepemimpinan di negara Indonesia yang terbukti memberikan pengaruh sangat besar terhadap kehidupan berpolitik dan bernegara. Dalam dunia bisnis, kepemimpinan berpengaruh sangat kuat terhadap jalannya organisasi dan kelangsungan hidupnya."
\end{abstract}

Kata Kunci: Perubahan Organisasi, Persaingan global.

\section{PENDAHULUAN}

Organisasi berasal dari kata organon dalam bahasa Yunani yang berarti alat (Khaerul Umam, 2010:22), Stephen P. Robbin (1990: 4), menyatakan, Organisasi yaitu:“An organization is a consciously coordinated social entity, with a relatively identifiable boundary, that function on a relatively continuous basis to achieve a command goal or set of goals. Organisasi adalah kesatuan sosial yang dikoordinasikan secara sadar, dengan sebuah batasan yang relatif dapat diidentifikasi bekerja atas dasar relatif terus menerus untuk mencapai suatu tujuan bersama atau sekelompok tujuan". Dari definisi tersebut, perkataan dikoordinasikan secara sadar mengandung pengertian manajemen. Kesatuan sosial berarti bahwa unit itu terdiri dari orang atau kelompok orang yang berinteraksi satu sama lain. Pola interaksi yang diikuti orang di dalam sebuah organisasi tidak begitu saja timbul, melainkan telah dipikirkan lebih dahulu. Oleh karena itu, karena organisasi merupakan kesatuan sosial, maka pola interaksi para anggotanya harus diseimbangkan dan diselaraskan untuk juga memastikan bahwa tugastugas yang kritis telah diselesaikan. Sebuah organisasi mempunyai batasan yang relatif dapat diidentifikasi. Batasan dapat berubah dalam kurun waktu tertentu 
dan tidak selalu jelas, namun sebuah batasan yang nyata harus ada agar dapat membedakan antara anggota dan bukan anggota. Batasan cenderung di capai melalui komitmen yang eksplisit maupun implisit antara para anggota dan organisasinya dalam peraturan organisasi yang disepakatinya.

Organisasi ada untuk mencapai sesuatu. "Sesuatu" ini adalah tujuan, dan tujuan tersebut tidak dapat dicapai oleh individu-individu yang bekerja sendiri, dan memungkinkan hal tersebut dicapai secara lebih efisien melalui usaha kelompok. Memperhatikan uraian tersebut, penulis menganggap cukup menarik jika perubahan organisasi pendidikan sebagai suatu sarana agar dapat mencapai tujuan atau menghadapi persaingan global di masa mendatang.

\section{PERUBAHAN ORGANISASI PENDIDIKAN}

Pada era globalisasi dan pasar bebas ini, menurut Sarbiran ( 2004: 29) ada beberapa tantangan yang dihadapi oleh lembaga pendidikan Islam di antaranya adalah: 1. Tantangan yang halus tidak tampak dan 2. Tantangan yang jelas atau langsung. hanya perguruan tinggi yang mampu melakukan perbaikan terus-menerus (continuous improvment) dalam pembentukan keunggulan kompetitif yang mampu untuk berkembang saat ini Perguruan Tinggi Agama Islam Swasta (PTAIS) dituntut harus berjalan dilandasi oleh keluwesan, kepercayaan, kejujuran, tanggungjawab, disiplin, visioner, peduli serta mampu mewujudkan kerjasama dengan team secara baik dan penyebaran informasi yang memadai. Sebaliknya, jika dalam suatu Perguruan Tinggi (PT) yang merasa puas dengan dirinya dan mempertahankan status quo akan tenggelam dan selanjutnya tinggal menunggu saat-saat kematiannya. Kepemimpinan yang memiliki peran sebagai salah satu penentu arah dan tujuan organisasi atau Perguruan Tinggi maka harus mampu mensikapi perkembangan zaman dan perubahan-perubahan pada era globalisai pada saat ini.

Pemimpin yang tidak mampu atau tidak dapat mengantisipasi perubahan di dunia yang berubah ini, atau setidaknya tidak memberikan respon secara cepat terhadap perubahan itu, besar kemungkinan akan memasukan organisasinya ke dalam keadaan situasi yang stagnasi dan akhirnya mengalami keruntuhan, perubahan-perubahan tersebut telah mengubah cara pandang sebuah organisasi dan para anggota organisasi dalam melakukan aktivitasnya. Pola-pola lama dan pendekatan-pendekatan tradisional yang selama ini diterapkan di dalam organisasi, tidak lagi mampu mengimbangi perubahan yang terjadi. Satu-satunya cara bagi organisasi untuk bisa mengikuti perubahan yang terjadi adalah dengan menyesuaikan diri 
atau beradaptasi dengan 'arus' yang baru. Jadi, orang yang membuat keputusan telah siap mengakses informasi. Salah satu struktur unit yang mendukung alur bebas informasi adalah grup strategi AES, grup ini menyediakan informasi tentang peubahan lingkungan, perkembangan teknologi, dan sejenisnya di seluruh perusahaan (Veithzal Riva'I, 2009:88). Penyesuaian-penyesuaian terhadap perubahan yang datangnya dari luar (outside-in), hanya akan membuat organisasi atau Perguruan Tinggi (PT) tersebut dapat bertahan hidup saja, tetapi tidak cukup untuk membuat organisasi tersebut mencapai tujuannya. Untuk itu diperlukan pendekatan-pendekatan yang sifatnya progresif dengan metode yang bersifat proaktif sehingga sebuah organisasi bahkan Perguruan Tinggi pun dapat menjadi organisasi yang efektif. Hal inilah yang akan membuat pendidikan bisa berhasil mencapai tujuannya untuk mewujudkan visi-misinya yang rahmatan lil a'lamin. Kebalikan dari pendekatan dari luar ke dalam (outside-in) adalah pendekatan dari dalam ke luar (inside-out) yaitu perubahan yang inisiatifnya berasal dari kesadaran para pemimpin dari dalam organisasi untuk berubah (Daniri, 2008). Kesadaran dan keinginan para pemimpin untuk berubah (transform) menjadi modal utama bagi proses transformasi Perguruan Tinggi menjadi organisasi yang menerapkan good university governance. Dalam Perguruan Tinggi yang menerapkan good university governance mengacu kepada sistem tata pemerintahan atau tata organisasi yang baik (Effendi, 2005). Sebagai sebuah sistem, good university governance dijalankan di atas beberapa prinsip dasar. Prinsip-prinsip tersebut adalah prinsip transparansi, akuntabilitas, tegaknya supremasi hukum, partisipasi anggota, kepedulian pada stakeholders, berorientasi pada konsensus, kesetaraan, visi strategis, dan efektifitas-efisiensi. Prinsip-prinsip tersebut harus diterapkan di dalam sebuah organisasi dan menjadi ukuran baik tidaknya good university governance di lembaga pendidikan tersebut. Secara universal, good university governance dipromosikan sebagai sistem tata Perguruan Tinggi yang akan membuat sebuah organisasi mampu melalui krisis dan mencapai tujuannya. Peran kepemimpinan di pendidikan mengemban amanah perlu mendorong perluasan penerapan good university governance ke berbagai unit-unit di lembaga pendidikan sangatlah penting. Perguruan Tinggi Agama Islam Swasta, sebagai Perguruan Tinggi swasta di Indonesia, telah menerapkan prinsip-prinsip good governance di dalam seluruh aktivitasnya, sesuai dengan tugas pokoknya sebagai lembaga penyelenggara pendidikan di Indonesia. Prinsip-prinsip yang ada dalam sistem good governance telah menjadi bagian dari sistem organisasi di lembaga pendidikan tersebut. Sehingga bisa dikatakan inilah action yang harus dilakukan para pemimpin yang mengemban amanah untuk mengantarkan lembaga pendidikan menuju Visi 
dan Misi mencapai tujuan organisasi, serta berdaya saing tinggi dan berilmu amaliah dan beramal ilmiah.

Perubahan yang dilakukan oleh pendidikan tersebut tidak hanya merombak fisik kampus, tetapi juga akan menata kembali sistem pengelolaan kampus, atau manajemen, agar lebih efisien dan berdaya guna. Oleh karena itu, diperlukan transformasi manajemen perguruan tinggi yang memenuhi tuntutan profesionalisme dan jaminan kualitas output (lulusan).

Transformasi manajemen yang diperlukan di dalam pengembangan pendidikan menurut UIN Jogjakarta (Pedoman UIN Jogjakarta) antara lain:

1. Redefining Vision \& Mission Of UIN, yaitu peninjauan kembali tentang visi dan misi institusi "sejauh mana dapat memberikan sumbangan" terhadap arah utama pendidikan tinggi Indonesia dalam membangun "Nation Competitiveness".

2. Encouraging Institution To The Need For Self-Evaluation, yaitu salah satu langkah awal untuk menentukan arah perbaikan serta rencana pentahapan pengembangan suatu institusi.

3. Formulating Strategic Plan, adalah suatu strategi untuk mencapai visi dan misi yang baru.

4. Redefining The University Governancel Organization, adalah usaha mewujudkan perangkat kelembagaan yang baik atau good governance dalam rangka pencapaian rencana strategik. Good university governance berfokus pada fairness, transparancy, accountability, responsibility.

5. Managing Organization With Redefined Vision \& Mission. Pada tahap ini, yang diperlukan adalah manajemen yang terpadu baik secara horizontal (antar eksekutif di tingkat tertinggi/universitas sampai dengan tingkat yang terendah/ Jurusan dan Program Studi) maupun secara vertikal (antara Rektorat dengan program studi).

Perubahan organisasi PENDIDIKAN sudah merupakan keputusan final yang tidak dapat dibalik lagi. Perubahan PENDIDIKAN ini menjadi penting karena dengan perubahan inilah PENDIDIKAN dapat bergerak lebih lincah. Lembaga pendidikan dapat menentukan pola proses pendidikan di setiap level organisasi. Lembaga pendidikan juga dapat menawarkan 
program pendidikan yang mampu memenuhi kebutuhan masyarakat. Dengan ciri ilmu keislaman yang kuat dan mentradisi maka lembaga pendidikan berpeluang menjadi pusat keunggulan baru dalam dunia pendidikan di Indonesia. Pusat keunggulan baru ini akan menjadi sebuah keniscayaan karena adanya model integrasi dan interkoneksitas dalam pengembangan ilmu.

\section{HUBUNGAN ORGANISASI PENDIDIKAN}

Tujuan organisasi lembaga pendidikan penuh dengan berbagai macam interaksi, pertentangan atau antagonistik antara dua atau lebih pihak dalam proses pencapaiannya. Memperhatikan susunan perguruan tinggi secara umum diatur oleh Peraturan Pemerintah No. 60 tahun 1999 tentang Pendidikan Tinggi. Hal ini seperti yang dikemukakan pada Bab VIII susunan Perguruan Tinggi, pada bagian kesatu, pasal 27, bahwa perguruan tinggi terdiri atas unsur-unsur: (a) dewan penyantun; (b) unsur pimpinan; (c) unsur tenaga pengajar/dosen; (d) senat perguruan tinggi; (e) unsur pelaksana akademik (pendidikan, penelitian, pengabdian pada masyarakat); (f) unsur pelaksana administratif; (g) unsur penunjang (perpustakaan, laboratorium). Selanjutnya pada pasal 29, pimpinan perguruan tinggi tersebut dalam melaksanakan tugasnya dibantu oleh: (a) Pembantu Rektor (Untuk Universitas/ Institut); (b)Pembantu Ketua (untuk Sekolah Tinggi); dan (c) Pembantu Direktur (untuk politeknik/Akademi). Untuk dapat berhasil menyelenggarakan fungsinya secara terencana dan teratur setiap perguruan tinggi harus menyusun perangkat serta membuat kerangka pengaturan, yaitu struktur dan organisasi kelembagaan. Jadi titik tolak pengembangan struktur dan organisasi ialah: menciptakan suatu kerangka pengaturan agar perangkat pelaksanaan dapat berfungsi dengan baik untuk mencapai tujuan perguruan tinggi. Acuan utama bagi perguruan tinggi dalam mengembangkan struktur dan organisasinya ialah bagaimana program fungsional dapat diselenggarakan dengan baik. Karena dalam menyelenggarakan fungsinya perguruan tinggi tidak mungkin terisolasi dari lingkungannya (pemerintah dan masyarakat pada umumnya), maka pengaturan atas interaksi antara perguruan tinggi dengan lembaga-lembaga lain juga menjadi acuan yang penting.

Meskipun asas otonomi diakui dalam pengelolaan perguruan tinggi, namun menurut penulis bahwa penerapan otonomi tidak terlepas dari: (1) pengaturan yang terbawa oleh faktor-faktor yang mempunyai hierarki yang lebih tinggi (supra sistem) dari sistem perguruan tinggi; (2) harapan dan pendapat masyarakat, yang pada dasarnya merupakan induk dan sumber perguruan tinggi; (3) aspirasi sivitas akademika, yang merupakan pelaku-pelaku 
utama dalam menyelenggarakan fungsi perguruan tinggi. Kalau siklus pengelolaan diawali dengan penetapan tujuan sasaran, pertama-tama harus diperhatikan kelaikan (feasibility) tujuan tersebut. Selanjutnya berdasarkan sumberdaya yang dapat disediakan dan tujuan yang ditetapkan, direncanakanlah program untuk mencapai tujuan. Jadi merencanakan program pada dasarnya merupakan upaya mengalokasi sumber daya dalam jumlah dan proporsi yang sesuai untuk dipadukan dengan prosedur tertentu guna menghasilkan tujuan. Hal ini dapat digambarkan seperti pada Perguruan tinggi merupakan suatu masyarakat sivitas akademika yang perilakunya sangat dipengaruhi oleh ilmu pengetahuan serta pengembangannya dalam kegiatan-kegiatan akademiknya.

Masing-masing pribadi anggota sivitas akademika secara fungsional menyandang kewibawaan akademik tertentu. Di pihak lain perguruan tinggi memerlukan sejumlah pribadi yang berfungsi untuk menyelenggarakan pengelolaan dengan mengusahakan keteraturan dalam kegiatan fungsional. Hal tersebut menyebabkan terjadinya sejenis dikotomi dalam penyelenggaraan dan pengelolaan perguruan tinggi, yaitu kewibawaan struktural birokrasi administrasi disatu pihak dan kewibawaan fungsional masyarakat akademik dilain pihak. Dengan adanya hal tersebut, maka pengambilan keputusan menjadi lebih rumit bila tidak terjadi rekonsialisasi antara kedua jenis kewibawaan tersebut. Kewibawaan struktural biasanya bersifat "rasional", dalam arti pola pengambilan keputusan dilandasi oleh prosedur dan format yang jelas dan baku, yaitu mengembangkan pilihan-pilihan dan alternatifalternatif untuk kemudian memilih yang optimal. Sedangkan kewibawaan fungsional di perguruan tinggi swasta biasanya terpecah-pecah karena mewakili berbagai disiplin ilmu. Kewibawaan fungsional juga sering bersifat ad hoc karena pengaruh kebutuhan berbagai disiplin ilmu yang berubah dengan waktu.

Oleh karena itu pengambilan keputusan juga sering bersifat ad hoc, dalam arti berlaku untuk waktu dan kebutuhan tertentu, serta sangat dipengaruhi oleh kepentingan pribadi. Dengan demikian konflik dalam organisasi lpendidikan merupakan sesuatu yang tidak dapat dihindari.

Menurut Jones A. F. Stoner dan Charles Wankel (1980: 216) bahwa: Konflik organisatoris merupakan suatu ketidaksesuaian paham antara dua orang anggota organisasi atau lebih, yang timbul karena fakta bahwa mereka harus berbagi dalam hal mendapatkan sumber-sumber daya yang langka, atau aktivitas-aktivitas pekerjaan, dan atau karena fakta bahwa mereka memiliki status-status, tujuan - tujuan, nilai-nilai atau persepsi-persepsi yang berbeda-beda. Berdasarkan definisi tersebut, dalam organisasi pendidikan pengambilan keputusan kerapkali 
harus didekati dengan tenggang rasa dan toleransi yang menyertai kewibawaan fungsional untuk menghasilkan pengambilan keputusan yang bersifat kompromi, bukan mufakat berdasarkan musyawarah, sehingga tanggung jawab pelaksana menjadi lemah. Tetapi kewibawaan fungsional seperti ini, yang menjadi landasan operasional otonomi keilmuan dan kebebasan akademik, masih merupakan sarana yang dianggap terbaik untuk mengembangkan ilmu, teknologi dan seni, sepanjang tidak terlalu diwarnai oleh kepentingan pribadi. Di masa yang Modern dan di era global ini lembaga pendidikan harus mampu menjalin komunikasi dan mampu menyelesaikan permasalahan serta mampu mengidentifikasinya. Yang terpenting lagi adalah antar lembaga pendidikan harus ada komunikasi yang sehat, agar lembaga pendidikan dapat berkembang dengan pesat.

\section{PERSAINGAN GLOBAL}

Pasar global tentu saja melahirkan tuntutan-tuntutan baru pada institusi pendidikan. Said Agil Sirodj (2004) menyatakan: Pemusatan yang berlebihan pada investasi Kapital memakan korban yang berujung pada rendahnya mutu, SDM, hilangnya kreativitas dan moralitas Bangsa. Salah satu pemicu tuntutan itu adalah pencapaian kemajuan teknologi informasi dan komunikasi yang berkembang semakin cepat. Bahkan, perkembangan teknologi informasi dan komunikasi telah mengikis batas-batas negara dan membantu menciptakan jaringan internasional. Pasar global jasa pendidikan merupakan kesempatan emas sekaligus tantangan terbesar yang harus dihadapi institusi pendidikan tinggi di masa depan. Pasar ini telah menciptakan persaingan global bagi institusi pendidikan tinggi. Implikasi persaingan global ini bukan saja dihadapi lembaga pendidikan tinggi, tetapi juga lulusan perguruan tinggi tersebut juga harus bersaing ketat. Mereka harus memperebutkan setiap kesempatan kerja yang ada dengan pesaing yang tidak hanya dari negaranya, tetapi juga internasional.

Persoalannya, mampukah institusi pendidikan memenuhi tuntutan pasar global? Mampukah pendidikan menyediakan layanan yang berkualitas, bisa memberikan nilai tambah pada dunia kerja, dan tidak meninggalkan nilai-nilai luhur bangsa? Siap atau tidak, tampaknya lembaga pendidikan harus berhadapan dengan pasar global ini. Lembaga pendidikan harus didorong untuk selalu dekat dengan persoalan masyarakat dan tidak selalu terjebak pada kursi menara gading. Bagaimana mendorong lembaga pendidikan untuk selalu dekat dengan stakeholders-nya sehingga lulusannya pun diterima masyarakat. Lembaga pendidikan juga harus mampu menjadi insitusi yang tidak melihat proses sebagai sesuatu yang mekanis dan tidak lagi mempunyai semangat pedagogis. Semangat pedagogis itu 
sangat dibutuhkan untuk memperbaiki mutu pendidikan nasional. Lembaga pendidikan juga menghadapi tantangan perubahan budaya organisasi yang semula sekadar menunggu instruksi menjadi sebuah lembaga yang mandiri dan memiliki inisiatif serta kebebasan untuk berekspresi mengembangkan bidang keilmuan yang dimilikinya dengan kekuatan anggaran yang dipunyainya.

\section{PEMBAHASAN}

Salah satu konsep sedang dipertimbangkan dan dirumuskan dalam perubahan manajemen yang diwujudkan dalam naskah akademik ini adalah perlunya model pengelolaan alternatif yang berbeda dengan model pengelolaan lembaga pendidikan masih konvensional. Manajemen yang terpadu baik secara horizontal (antar eksekutif di tingkat tertinggi/ universitas sampai dengan tingkat yang terendah/ Jurusan dan Program Studi) maupun secara vertikal (antara Rektorat dengan Jurusan) merupakan syarat utama agar pelaksanaan operasional dan pelayanan pada mahasiswa dan masyarakat luas dapat berlangsung secara efektif dan efisien. Pengelolaan perguruan tinggi saat ini dihadapkan pada pilihan-pilihan antara sentralisasi dan desentralisasi administrasi dan akademik demi tercapainya efisiensi dan efektifitas pengelolaan organisasi. Model pengelolaan terpadu ini dimaksudkan pula sebagai salah satu jawaban dari sekian banyak tantangan yang sedang dan akan dihadapi oleh lembaga pendidikan.

Realitas globalisasi yang demikian membawa sejumlah implikasi bagi pengembangan SDM di Indonesia. Salah satu tuntutan globalisasi adalah daya saing ekonomi. Daya saing ekonomi akan terwujud bila didukung oleh SDM yang handal. Untuk menciptakan SDM berkualitas dan handal yang diperlukan adalah pendidikan. Sebab dalam hal ini pendidikan dianggap sebagai mekanisme kelembagaan pokok dalam mengembangkan keahlian dan pengetahuan. Pendidikan merupakan kegiatan investasi di mana pembangunan ekonomi sangat berkepentingan. Sebab bagaimanapun pembangunan ekonomi membutuhkan kualitas SDM yang unggul baik dalam kapasitas penguasaan IPTEK maupun sikap mental, sehingga dapat menjadi subyek atau pelaku pembangunan yang handal. Dalam kerangka globalisasi, penyiapan pendidikan perlu juga disinergikan dengan tuntutan kompetisi. Oleh karena itu dimensi daya saing dalam SDM semakin menjadi faktor penting sehingga upaya memacu kualitas SDM melalui pendidikan merupakan tuntutan yang harus dikedepankan. Salah satu problem struktural yang dihadapi dalam dunia pendidikan adalah bahwa pendidikan merupakan subordinasi dari pembangunan ekonomi. 
Pada era sebelum reformasi pembangunan dengan pendekatan fisik begitu dominan. Hal ini sejalan dengan kuatnya orientasi pertumbuhan ekonomi. Visi pembangunan yang demikian kurang kondusif bagi pengembangan SDM, sehingga pendekatan fisik melalui pembangunan sarana dan prasarana pendidikan tidak diimbangi dengan tolok ukur kualitatif atau mutu pendidikan. Problem utama dalam pembangunan sumberdaya manusia adalah terjadinya missalocation of human resources. Pada era sebelum reformasi, pasar tenaga kerja mengikuti aliran ekonomi konglomeratif. Di mana tenaga kerja yang ada cenderung memasuki dunia kerja yang bercorak konglomeratif yaitu mulai dari sektor industri manufaktur sampai dengan perbankan. Dengan begitu, dunia pendidikan akhirnya masuk dalam kemelut ekonomi politik, yakni terjadinya kesenjangan ekonomi yang diakselerasi struktur pasar yang masih terdistorsi. Kenyataan menunjukkan banyak lulusan terbaik pendidikan masuk ke sektor-sektor ekonomi yang justru bukannya memecahkan masalah ekonomi, tapi malah memperkuat proses konsentrasi ekonomi dan konglomerasi, yang mempertajam kesenjangan ekonomi. Hal ini terjadi karena visi SDM terbatas pada struktur pasar yang sudah ada dan belum sanggup menciptakan pasar sendiri, karena kondisi makro ekonomi yang memang belum kondusif untuk itu. Di sinilah dapat disadari bahwa visi pengembangan SDM melalui pendidikan terkait dengan kondisi ekonomi politik yang diciptakan pemerintah.

Sementara pada pasca reformasi belum ada proses egalitarianisme SDM yang dibutuhkan oleh struktur bangsa yang dapat memperkuat kemandirian bangsa. Pada era reformasi yang terjadi barulah relatif tercipta reformasi politik dan belum terjadi reformasi ekonomi yang substansial terutama dalam memecahkan problem struktural seperti telah diuraikan di atas. Sistem politik multipartai yang telah terjadi dewasa ini justru menciptakan oligarki partai untuk mempertahankan kekuasaan.

Pemilu 2014 yang konon merupakan pemilu paling demokratis telah menciptakan oligarki politik dan ekonomi. Oligarki ini justru bisa menjadi alasan mengelak terhadap pertanggungjawaban setiap kegagalan pembangunan. Dengan demikian, pada era reformasi dewasa ini, alokasi SDM masih belum mampu mengoreksi kecenderungan terciptanya konsentrasi ekonomi yang memang telah tercipta sejak pemerintahan masa lalu. Sementara di sisi lain Indonesia kekurangan berbagai keahlian untuk mengisi berbagai tuntutan globalisasi. Pertanyaannya sekarang adalah bahwa keterlibatan Indonesia pada liberalisasi perdagangan model AFTA, APEC dan WTO dalam rangka untuk apa? Bukankah harapannya dengan keterlibatan dalam globalisasi seperti AFTA, APEC dan WTO masalah kemiskinan dan 
pengangguran akan terpecahkan. Dengan begitu, seandainya bangsa Indonesia tidak bisa menyesuaikan terhadap pelbagai kondisionalitas yang tercipta akibat globalisasi, maka yang akan terjadi adalah adanya gejala menjual diri bangsa dengan hanya mengandalkan sumberdaya alam yang tak terolah dan buruh yang murah. Sehingga yang terjadi bukannya terselesaikannya masalah-masalah sosial ekonomi seperti kemiskinan, pengangguran dan kesenjangan ekonomi, tetapi akan semakin menciptakan ketergantungan kepada negara maju karena utang luar negeri yang semakin berlipat.

Oleh karena itu, untuk mengantisipasi tuntutan globalisasi seyogyanya kebijakan link and match mendapat tempat sebagai sebuah strategi yang mengintegrasikan pembangunan ekonomi dengan pendidikan. Namun sayangnya ide link and match yang tujuannya untuk menghubungkan kebutuhan tenaga kerja dengan dunia pendidikan belum ditunjang oleh kualitas kurikulum sekolah yang memadai untuk menciptakan lulusan yang siap pakai. Yang lebih penting dalam hal ini adalah strategi pembangunan dan industrialisasi secara makro yang seharusnya berbasis sumberdaya yang dimiliki, yakni kayanya sumberdaya alam (SDA). Kalau strategi ini tidak diciptakan maka yang akan terjadi adalah proses pengulangan kegagalan karena terjebak berkelanjutannya ketergantungan kepada utang luar negeri, teknologi, dan manajemen asing. Sebab SDM yang diciptakan dalam kerangka mikro hanya semakin memperkuat proses ketergantungan tersebut.

Bangsa Indonesia sebagai negara yang kaya akan SDA, memiliki posisi wilayah yang strategis (geo strategis), yakni sebagai negara kepulauan dengan luas laut 2/3 dari luas total wilayah; namun tidak mampu mengembalikan manfaat sumber kekayaan yang dimiliki kepada rakyat. Hal ini karena strategi pembangunan yang diciptakan tidak membangkitkan local genuin. Yang terjadi adalah sumber kekayaan alam Indonesia semakin mendalam dikuasai oleh asing. Sebab meskipun andaikata bangsa ini juga telah mampu menciptakan SDM yang kualifaid terhadap semua level IPTEK, namun apabila kebijakan ekonomi yang diciptakan tidak berbasis pada sumberdaya yang dimiliki (resources base), maka ketergantungan ke luar akan tetap berlanjut dan semakin dalam. Oleh karena itu harus ada shifting paradimn, agar proses pembangunan mampu mendorong terbentuknya berbagai keahlian yang bisa mengolah SDA dan bisa semakin memandirikan struktur ekonomi bangsa. Supaya visi tersebut pun terjadi di berbagai daerah, maka harus ada koreksi total kebijakan pembangunan di tingkat makro dengan berbasiskan kepada pluralitas daerah. Dengan demikian harapannya akan tercipta SDM yang di hasilkan oleh lembaga pendidikan yang 
mampu memperjuangkan kebutuhan dan penguatan masyarakat lokal. Karena untuk apa SDM diciptakan kalau hanya akan menjadi perpanjangan sistem kapitalisme global saja.

\section{KESIMPULAN}

Kehadiran lembaga pendidikan di tengah masyarakat pada dasarnya merupakan perwujudan dari suatu cita-cita yang telah lama terkandung di hati sanubari umat Islam Indonesia. Hasrat untuk mendirikan semacam lembaga pendidikan tinggi Islam itu bahkan sudah dirintis sejak zaman penjajahan. Perubahan lembaga pendidikan sudah merupakan keputusan final yang tidak dapat dibalik lagi. Perubahan lembaga pendidikan ini menjadi penting karena dengan perubahan inilah lembaga pendidikan dapat bergerak lebih lincah. Lembaga pendidikan dapat menentukan pola proses pendidikan di setiap level organisasi. Lembaga pendidikan juga dapat menawarkan program pendidikan yang mampu memenuhi kebutuhan masyarakat. Dengan ciri ilmu keislaman yang kuat dan mentradisi maka lembaga pendidikanIslam berpeluang menjadi pusat keunggulan baru dalam dunia pendidikan di Indonesia. Pusat keunggulan baru ini akan menjadi sebuah keniscayaan karena adanya model integrasi dan interkoneksitas dalam pengembangan ilmu, dan akan mampu berdiri dengan tegak dimasa globalisasi ini.

Lembaga pendidikan Islam harus selalu berbenah, apalah arti sebuah visi global bila tidak dimbangi dengan SDM yang mengikuti perkembangan. Lembaga pendidikan Islam harus selalu mawas diri tidak mudah puas dengan capaian - capaian pada saat ini bila masih ingin tetap eksis sebagai lembaga Pendidikan Tinggi Islam yang diterima tidak saja oleh masyarakat Islam tapi bisa diterima, diakui dan dapat berdiri sejajar dengan Perguruan Tinggi berlevel Internasional.

\section{Daftar Pustaka}

Amir, M. Taufiq, 2006 Belajar Manajemen dari Konteks Dunia Nyata, Yogyakarta, PN. Graha Ilmu.

Bangun, Wilson SE, MSi,DR, 2008. Intisari Manajemen, Bangung, PT. Refika Aditama.

Blanchard, Kenneth Ph.D dan Robert Lorber, Ph.D, 1985, Manajer satu Menit Dalam Praktek, Jakarta, PN. Erlangga. 
Buhler, Patricia, alih bahasa oleh Sugeng Haryanto dkk, 2007. Alpha Teach Yourself: Management Skills dalam 24 Jam, Jakarta, Prenada.

Depag RI, 2000. Problem dan Prospek IAIN, Jakarta, Depag RI

Fak Tarbiyah UIN Sunan Kalijaga, 2004. Pendidikan Islam dan Tantangan Gkobalisasi, Jogjakarta, Presma.

Gaspersz, Vincent, 2001. Iso 1900: 2000 And Continual Quality, Jakarta, Gramedia.

Hakim, M. Arief, 2005. Kiat Menulis Artikel di Media dari Pemula sampai Mahir, Bandung PN. Nuansa Cendekia.

Hubeis, Musa, 1995. Analisa Potensi Diri (Mengukur Potensi Manajerial Anda), Jakarta PN. Erlangga.

Jackson, Terence alih bahasa F.X. Budiyanto, 1995. 50 Aktivitas untuk Mengembangkan Ketrampilan Manajemen Volume 4, Jakarta, Binarupa Aksara.

Kusmana dkk Editor, 2008. Paradigma Baru Pendidikan Islam, Jakarta, Depag RI.

M. Herujito, Yayat, 2001, Dasar-dasar Manajemen, Jakarta, Grasindo.

M. Romli, Asep Syamsul, 2001. Jurnalistik Praktis, Bandung PN. PT Rosdakarya.

Rochaety, Ety, DR, dkk, 2006. Sistem Informasi Manajemen Pendidikan, Jakarta, PN. PT. Bumi Aksara.

Supratikno, Hendrawan, dkk, 2003. Advanced Strategic Management, Jakarta PN.Gramedia.

Umam, Khaerul Umam, 2010, Prilaku Organisasi, Bandung, Pustaka Setia.

Rivai, Veithzal, MBA, DR, Prof, dan Arfian Arifin, Ir, 2009 Islamic Leadership(Membangun Superleadership melalui kecerdasan spiritual), Jakarta, PT.Bumi Aksara. 